\title{
The Nordenfelt Machine Guns (Palmcrantz's System)
}

\section{T. Nordenfelt Esq.}

To cite this article: T. Nordenfelt Esq. (1881) The Nordenfelt Machine Guns

(Palmcrantz's System), Royal United Services Institution. Journal, 24:108, 785-800, DOI:

10.1080/03071848109418526

To link to this article: http://dx.doi.org/10.1080/03071848109418526

册 Published online: 11 Sep 2009.

Submit your article to this journal $[\pi$

Џll Article views: 8

Q View related articles ¿ 


\section{Thine dourmal}

\section{OF. THE

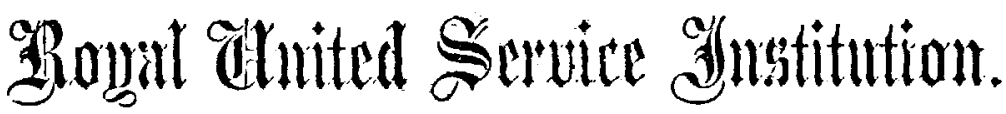

VoL. XXIV. $1881 . \quad$ No. CVIII.

Monday Evening, June 28, 1880.

Admiral Sir FREDERICK T. E. NICOLSON, Bart., C.B., Chairman of the Council, in the Chair.

\section{THE NORDENFELT MACHINE GUNS (PALMCRANTZ'S SYSTEM).}

By T. Nordenfelt, Esq.

Trme does not allow me to enter into the history and development of the Nordenfelt machine guns, which on the Continent are called the "Nordenfelt-Palmcrantz" guns, the name of my clever friend Palmorantz, who originally invented the mechanism, and who still works with me at Stockholm in our common iuterest and object in developing and perfecting these machine guns, being added.

I may be allowed to state at once that I differ from those gentlemen who consider machine guns as competing with artillery. I hold them to be special weapons, invaluable for special purposes, mostly created by the great advance during late jears in all other branches of the science of war.

The appearance of the first ironclad on the American waters was the signal for wooden navies to depart. The "wooden walls of old "England" were no longer to be trusted; they had indeed become relics of the past, with a most glorious history but without a fature.

The monstrons ironilad with her heavy ordnance would receive a fall broadside from a threc-decker with as little effect as a hailstorm would produce on the back of a tortoise, while she could cut the wooden ship into pieces with her ram. The ironclad scemed to reign supreme, constantly increasing in size, armour, and ordnance, until doubt was'shrown upon the wisdom of having too large vessels by the appearance of a tiny foe, generated by science-a very scorpion of the deop-one touch of whose fiery tongue could send the noblest ironclad to the bottom of the sea.

The torpedo-boat had, therefore, to be met by special weapons, and machine gans came to the front ready to deal with it so effectually that a daylight attack now becomes almost an impossibility, and it voL. XXIY. 
requires a stout heart to volunteer to attack in a torpedo-boat eren at night.

NFachine guns must also be acknowledged sooner or later as invaluable against the modern swift unarmoured ships which, with their speed of 15 to 18 linots, give but little chance to the present recoil gans.

In the Army also there has been an almost complete revolution in the reapons of warfare. The reapons used by TVellington are obsolete. Rifled cannons have increased the precision and effect of projectiles to an extent previously unknown, and at the same time they have enabled artillerists to fire at enormous ranges.

The rifle has given the same adrantages to the infantry; and'still the repeating, or magazine rifle is pressing on the ordinary breechloader. It has, however, yet to be proved that for general service with deliberate aim, when the target is an enemy for each shot, the ordinary breech-loader is not, on the whole, more satisfactory; while when firing agninst columns or moving bodies of infantry or caralry, or against earthworks or parks of artillery, the light, smallbore, machine gun must be by far the most effective.

I look upon machine guns as mechanical contrivances for economizing human labour and human life in war. They are to the art of war what Arkwright's spinning jenny was to weaving. He enabled a few people to produce as much yarn in an hour as scores employing the "turn" with its single spindle could make in a day-and even the turn was a great advance upon the distaff. The machine guns have, for special purposes, the same superiority over the breech-loader, the old Enfield rifle, and "Brown Bess."

The men at Crecy and Agincourt fought with the long bow, which could strike a target at six score yards; but these heroes would, even with the Black Prince to command them, have been practically defenceless against the "Brown Bess" in the hands of the poorest of disciplined troops.

The man who invented the sling that would "throw a stone to a " hand's-breadth," puta weapon into the hands of the lad David which made him a match for the giant-terrible fellow though he was.

All experience, especially of the last 20 years' wars, tends to prove that the best weapon does as much or more to secure victory as the best man; and that the best armed man is often master of the situation under very adverse circumstances, and is always the conqueror if his discipline is as good as that of his enemy.

The supposed difficulty of supplying ammunition for a machine gun in the ficld is not great-always granting that the gun uses the same ammunition as the rifle; because for most purposes for which a machine gun would be used, it would fire at spurts of only a few secondis at a time with so much more effect, both actual and moral, under these special circumstances than ordinary rifle firing, that the total ammunition fired from the machine gun would probably not exceed what would have to be fired by the corresponding number of rifles before the same object were gained.

The Turks, moreover, during the late war gave a severe lesson 
to those who would retard the development of arms for fear of the difficulty of supplying ammunition, by proving that even with their inferior organization and wiserable transport, the supply of ammunition can alwajs be relied upon, as soon as the paramount importance of this supply is fully understood.

The question of expense for a country like England is also relative, for if machine guns can shorten a war by a week, or can prevent the blockide of a single colonial port, the possible expense for extra supply of ammunition must be repaid tenfold.

\section{General Description of Machine Guns.}

In order to give a clear description of the guns generally, ] musi. divide inachine guns as seen from two different points of view :-

First. - (a.) M Iachine gans with revolving barrels which cannot firt volleys. (b.) Guns with fixed barrels, and which can fire either volleys or single shots as desired.

Second.-(I.) Mrachine guns firing the same projectiles as the riflis of each country. (II.) Machine guns firing projectiles of larger calibre than rifle calibre, principally for the purpose of penetrating ships' plates, boilers, \&c.

My, machine guns have fixed barrels, and can always fire volleys, unless any Porrer prefers to subwit to single firing for the purpose of gaining lightness and simplicity. They are also equally well adapted for small and for large calibres.

The Gatling gun is the original type of the opposite system with revolving barrels, which cannot fire rolleys, and I hope that Dr. Gatling will excuse my saying that his revolving gun, with movable breech supports, is tied down to the first part of my second basis of division, viz., that his gun can only fire rifle ammunition with advantage. The Hotchkiss gun ${ }^{1}$ is a development of the Gatling iden with revolving barrels, and cannot fire volless, but with his solid breech support he has gained the point of being able to fire projectiles of large calibre; while, on the other hand, he has lost rapidity of fire, so that his system is impossible for rifle ammunition. Mr. Hotchkiss, therefore, naturally condemns all machine guns which fire rifle ammunition, and brings his large experience to bear upon competition with artillery in firing shells.

The Gardener gun lies between the tro in the first division. It fires with fixed barrels or rather barrel, but it cannot fire volleys; and I believe that it only fires rifle ammunition.

I would, however, hardly class the Gardener gun with machine guns, because the single-barrelled gun which Mr. Gardener himself especially recommends is rather a clever repenting rifle, while it at the same time requires the full service of men and equipment of a machine gun.

Of all other machine guns such as the Montigny, the Albertini, the Lowell, the 'I'rotter, the Rowbottom, and numerous others, I can only say that some are like flowers that have already withered and belong

1 See Juurnal, No. CV, p. 279 et seq. 3 II 2 
to the past, while others still show only in the bud witkout any immediate prospect of coming into bloom.

I mast apologise for thus bringing in the leading featares of other guns, but I have thought it necessary, in order to illustrate the principal points in which we differ, and I now proceed to describe the mechanism and use of my own gun.t

In the Palmerantz system the barrels are fixed in a level line, or in an arch, the breech supports are brought forward to the barrel chambers, pushing the cartridges in front of them, then the breech is locked, the cartridges fired; the breech unlocked, and the fired cartridge cases extracted by the retiring breech plugs. The fresh supply of a layer of cartridges is provided by the cartridge receiver, which by a traversing motion carries the cartridges from the compartments in the feed case, which correspond to the barrels, into a line. with the rear of the chamber, "ready to 'be pushed in by the next forward motion of the breech plugs.

The cartridges are kept in hoppers or feed cases, with one compart. ment for each barrel, so that I can at any time control the fire of each barrel. When continuous firing is desired, the hoppers are double, so that the upper hopper is changed, while the contents of the lower lopper are being fired.

The entire movement of the mechanism results from tho forward and backward morement of the firing lindle, so that one single gunner can fire withont ang assistance with liis right hand rapidly an entire hopper full of cartridges varying from 40 to 200 shots, while his left hand is freo to attend to the elevating and traversing gear. The trigger comb is locked during the forward and rearward motion of the firing handle, so that no shot can be fired when the springs are compressed until after the recoil bolts have locked the action block and breech plugs. This locking of the trigger comb is a recent modif. cation, in order to make the guns quite safe from premature explosions of cartridges.

The gans can fire single shots or volleys as desired; when firing single shots, the recuil is 'very slight indeed, and when firing volleys, the shots are not fired absolutely at the same moment, bat follow one another extremely rapidly,-so that'the recoil of a volley has only about two-thirds of the effect which it would have if the shots were fired absolutely at the same moment. The recoil bolts which lock the action block, when in firing position, bring the recoil to bear upon the cntire frame and mounfing of the gun, so that the total weight of the gun is sufficient to resist the recoil, always supposing the gan to be properly fixed to its mounting or carriage.

For land service we have applied an automatic scattering motion, which can be adjusted in order to spread each volley horizontally along the front of the enemy at varying ranges.

The mechanism is made of the very best forged steel, and all the parts are so anply strong for tho work they have to perform, that no breakage is likely to occur.

The cartridges, which fall straight into the cartridge receiver, have

1 For full details, see Plate and Appendix. 
only to travel their own length into the chambers and ont again, and the empty cases drop, from their own weight, out of the cartridge receiver, so that with the comparatively slow morement of the mechanism no jambs,or hitches are likely to be caused by the mechanism. In case any hitch should be caused by an imperfect.cartridge, I have ouly to raise the cover by pressing the spring-lock with one finger, when the mechanism is laid bare so that $I$ ran touch at once every firing needle and extractor, and so that $I$ can remove the cartridge or clean the chambers, which are then so.open and accessible, that I can put my finger rictht into all the barrels from the brecch end as well as from the muzzle end, and can clean them from either end.

The catire mechanism can be taken out of the gun without a single tool in a few seconds, and the spiral springs can be taken out in a moment, and replaced without any tools and without even raising the cover or opening up of the mechanism. As a separate cocking piece has lately been added to the gun, the hammers have now nothing more to do than to strike the firing needles, and the hammers and spiral springs are now so amply strong for the work they have to do, that no breakage of any lind has occurred even at the excessively rapid firing during the last few months at Portsmouth and at Shoeburyness.

If a faulty cartridge case should fail to be extracted and remain in the chamber, the remaining barrels can still be fired without any stoppage, by a sliglit donble motion of the handle, which throws out the cartridge which corresponds to the barrel which is disabled, and if one or more barrels are damaged in transport or by the enemy's fire, the remaining barrels can still be fired, because I can control the compartment in the hopper belonging to each barrel, so that I only have to fill the compartments corresponding to the barrels which remain in good condition.

As the breech plugs close up from the rear, in line with the chambers, this gan is much less affected by possible dirt or fouling than guns where the brecci closes from the side.

The mechanism itself is well covered, but the cartridge carrier is open both above and below, so that no dirt can collect in it to prevent the easy run of the cartridges, and I hold this to be one of the principal adrantages, that it is unlike the revolving guns, where the chamber-ends of the barrels and the entire breech are covered up and not easily accessible.

I wish especially to point out that the fact of our system having fixed barrels is very advantageous, not only because it saves the work of revolving the barrels, but also because, when we come to larger calibres, we can use heavier charges of powder per calibre, without unduly increasing the weight of the gun; whereas in a revolving gun, with barrels of large calibre, and with heary charges of powder which necessitate considerable thickness of steel in the barrel, the pressure of the explosion of the cartridges acts so far from the centre of the revolviug motion, that all these parts must be made especially strong and heary in order to prevent their being bent or apset, which would 
hinder the smooth action of the two revolving surfaces, viz., the chamber base and the face of the breech.

Dr. Gatling has seen the importance of this, and has provided a regulator for adjusting the distance between chanber and breech; but this regulator is, on the other hand, rather a source of trouble, and it requires great judgment on the part of the gunner; and if used incorrectly, might throw the gun ont at an important moment.

\section{Calibres.}

We make machine guns of the following calibres:-

(a.) Rifle calibre, varying from 0.33 to 0.56 inch, and we have made such machine gans for the Martini-Henry, Snider, Peabody, Gras, Miauser, Berdan, Wetterli, Remington, and Comblain cartridges, varying from 5 to 10 barrels in each gun; the weight of these guns varying from $100 \mathrm{lbs}$. to $260 \mathrm{lbs}$., depending principally upon the number, length, and weight of barrels with corresponding varying strength of frame and mechanism.

- (b.) 1-inch calibre, specially for naval use for defence against torpedoboats. We make these with four barrels, like the English naval l-inch gun, weighing 4 cwts., or with two barrels, weighing about $2 \frac{1}{2} \mathrm{crts}$., the latter more especially for use in the tops and in boats, for which purpose the mounting is so arranged that the gun can be easily and quickly mored from one place to another.

(c.) $1 \frac{1}{2}$-inch calibre for general naval use for firing $1 \frac{1}{2}$-lb. shells against unarmoured ressels, and for field service and fortifications.

We make these with one barrel when the gun weighs 2 cwts., and with two barrels when the gun weighs about $4 \frac{1}{2}$ cwts.

We hare also in work a $1 \frac{7}{8}$-inch and a 3-inch gun for firing respectively $3 \frac{1}{2}$ and $12 \mathrm{lbs}$. projectiles, but these are not yet so far advanced that I can give any definite details.

\section{For Field Use}

there are two entirely separate kinds of machine guns: the one is a shell-firing gun, which wonld compete with feld artillery, which Mr. Hotchkiss has worked out with a certain amount of success. As to this I can to-day only say that I hope shortly to be in a position to show that the effect produced by the Hotchkiss gun can be produced by a smaller number of fixed barrels and lighter weight of gun, when the advantage might perhaps be beld out to the artillery that the same weight of metal in the shape of small shells, spread more evenly over a surface, may be thrown per minute by a gun of smaller calibre and light weight than what is now done by the present light field gun; on this point, however, I do not speak at the present moment with much confidence.

The other kind of machine gun is the much-abused small-bore battery gun or mitrailleuse, as representatives of which I take my ten-barrelled gun, which woighs $2 \frac{1}{2}$ cwts., and fires 110 MIartini-Henry bullets in five seconds, and my five-barrelled gun, which weighs from $110 \mathrm{lbs}$. to $135 \mathrm{lbs}$, and fires 70 shots in five seconds. 
The ten-barrelled gun is of course the most effectire, bnt it requires two borses for gun and limber.

The heavy machine gun got into sad disgrace during the FrancoPrassian War, when the old MIontigny was outlawed-but then it must be remembered that the mitrailleuse of that day fired slowly, and not continuously; that it weighed three times as much as mine, and that it consequently required six horses. It could not be moved quickly, and its tactics consequently exposed it to be destroyed by the enemy's field guns. It also had the fatal fault that it required a special cartridge, so that often when the mitrailleuse was relied upon by a General it was worse than useless if the wrong ammunition had been brought up; besides which, a second kind of small arms ammunition in the field also created confusion in the supply of cartridges to the infantry.

This is one reason why I think it hopeless at present to introdace a machine gun which fires small shells in competition with the present field guns, because this would introduce a new kind of ammunition, whereas $\mathrm{my}$ ten-barrelled gun woald fire the rifle ammunition which already is in the field, and would prove invaluahle in the hands of tacticians and strategists, who understood how to make use of a weapon which, from one point and under cover, fires an exceedingly rapid succession of volleys, cach volley of ten shots being spread over a surface which I can adjust by the automatic spreading motion as desired.

Within a range of 1,500 yards a gun could hardly be brought up to destroy the mitrailleuse in face of the heary rain of bullets.

The question of the use of these ten-barrelled guns in the field will probably require further study and consideration, bat there can be no doubt that for the defence of 'bridges, roads, and temporary intrench. ments, they must be most useful.

An entirely new phase in the use of mitrailleuses has, howerer, been opened up by the small five-barrelled gun which weighs less than onethird of the service Gatling gun, while it fires much more rapidly, say about 500 rounds per minute, or, for spurts of 100 shots at the time, at the rate of nearly 800 shots per minute.

This gun with its limber on wheels can be drawn by one mule or by three men; it can be carried on one horse, with the trail on a second horse, or the gun and pivot can be carried all on one horse; when required, the gun and pirot can be carried on the shoulders of three men, who also carry the ammunition in special knapsacks.

This gun has nothing to do with artillery at all; it is simply a combination of five repeating rifles, with magazines, fired by one man : it gives a General the best chance of a monnted infantry which can be sent forward quickly in advance to occupy points of vantage, or which in retreat can hold on to important points to give the infantry time to retire, step by step; for attack as well as defence of baggage trains and convoys of ammunition it wonld also be usefnl.

A troop of cavalry with a mounted machine gun could do much in harassing and in surprising an enemy on the march, and a clever Officer with a couple of machine guns on horse-back could generally 
creep up near enough to an enemy to have a few seconds' destructive fire at the caralry or artillery of the enemy.

These guns would also be useful for dropping fire against trenches, and for defence of intrenchments or of an open camp: they could be lept close at hand, and be brouglit into play at the all-important moment when the enemy storms the position. $A$ glacis defended by mitrailleuses could hardly be stormed at all, and a breach conld not be passed against mitrailleuses under cover with cross-fire into the breach.

I cannot but think that it would be specially nseful in colonial wars against hordes of undisciplined natives, for lill work, and for defence of depôts, camps, and Jaagers.

I have mentioned a few of the many special occasions when I think that a mitrailleuse firing the same ammunition as the rifle would be usefal, independently of artillerg, and I leare it to Officers who have commanded in the field to consider how far it would be advisable to provide such weapons for these special occasions; as no special ammunition is required for them, it would not be very difficult to let a certain number follow each brigade.

\section{For Naval Use.}

I begin with the small-bore machine gun, and here again there is use for both a ien-barrelled and a five-barrelled gun.

As these gans use the same ammunition, and as the system is the same, it is no disadrantage to have both guns in the Service, because crery sailor who can fire the one can also fire the other.

On large vessels two ten-barrelled gans in fixed position on deck would be most effective for sweeping the decks of an enemy's vessel.

Its volleys of ten shots cach with the slight vibration of the gun would have sufficient spreading without any scattering motion; the angle of descent at long ranges, and a fer rapid volleys at shorter ranges when the enemy's ship heels over, would be most effective, and a steady succession of volleys of ten shots at his gun ports would distarb the service of his guns.

All the faster unarmoured vessels and all gunboats, where there would be no question of moving the guns from one place to another during action, could also have one of the ten-barrelled guns, as well as their complement of larger calibre machine guns.

The five-barrelled guns, again, would be fitted to the tops of all larger ressels and in steam launches, and generally where they are required to be mored quickly from one point to another during action. They might also be fitted to torpedo-boats for firing agrainst other boats, against anti-torpedo guns during attack, and against the electric ligits of the enemy's vessel the moment they are found out, and previous to or during the actual attack.

I have not liked to say much about what these guns have done, becanse they are still under the consideration of the Machine Gun Committee, whose experiments will be continued as soon as we shall have completed new guns for the new ammunition decided upon by the Committee, in lieu of the present service ammunition, for which latter the guus were first made. 
I think, however, that I may say that my guns have done at least as well as those of $\mathrm{my}$ competitors, and that I can therefore offer one and the same satisfactory system throughout all the calibres required by the Navy.

While I am fully aware it would be wrong to lose any one advantage on board for portability and conrenience ashore for naval guns, still ruy small five-barrelled gan is so very suitable for landing purposes that this should not be lost sight of. Three sailors can prill the grun and limber; four sailors can carry the gun and trail in case the wheels have to be left behind; and the ammunition is kept in knapsacks in the limber, ready to be carried wherever the limber cannot be conveniently taken. With six or eight men this gun would be as well served as the Serrice Gatling with $18 \mathrm{men}$, and it fires more quickly, and is much more simple and not likely to jamb.

\section{Anti-torpeclo-boat Gun.}

For this special purpose it is quite clear to me that the right calibre is the smallest calibre which gires sufficient penetration, viz., 1 inch; hecause the smaller the calibre, the larger the number of barrels that I can use in each gun, the greater number of shots I can fire in cach volley, with correspondingly greater chance of hitting, and the more I can increase the actual rapidity of fire as the range against an attacking torpedo-boat gets shorter, and the effect of each bullet proportionately greater.

I look upon volley firing as an absolute necessity for naval machine guus, as long as the consideration of weight or portability of the gun does not make it necessary to submit to single shots. It is quite true, for instance, that the Gatling gun can give a steady stream of bullets with constantly incrensing depression, but this line of hits becomes very unsteady when the vessel rolls or pitches, and very ineffective when the object fired at moves, while my own ship follows the movement of the waves. Then it becomes necessary to fire volleys, because I have to aim alcad of the moving vessel to allow for the time of flight of the projectiles. I hare to fire while my own ship rises just before it turns, and as $I$ have to judge my distance and change my sight to an always varying range, it is the volley with the slight spreading caused by the vibration of the weapon which gives me the best chance of hitting.

I shall hardly bo contradicted in saying that these are the most frequent conditions under which firing is done at sea.

This gun fires steel ballets weighing somewhat less than $\frac{1}{2} \mathrm{lb}$. cach, with an initial relocity of about 1,400 feet, which gives a maximum penetration, at 200 yards, of $\frac{3}{4}$-inch steel plate at right angles, $\frac{1}{3}$-inch steel plate at $25^{\circ}$ angle, and $\frac{3}{18}$-inch steel plate at $20^{\circ}$ angle, while it penetrates the side of a second class torpedo-boat at $10^{\circ}$ angle, tearing up a hole many times larger than the bullet. It goes straight through a torpedo-boat (in and ont again) at a distance of an English mile at right angles. It penetrates the side of a torpedo-boat and its boiler at $45^{\circ}$ angle at 300 yards, and it penetrates the bow of a torpedo-boat, 
four bulk-heads, and the boiler at 200 sards range, while its energs, after having passed through the bow of the boat and the bulkheads, is quite sufficient for breaking or otherwise spoiling any piston or connecting rod, cylinder, or fire-box which it may hit, or to pass out of the boat under the water-line on the opposite side if it does not hit the machinery before.

A projectile which does not actually penetrate the boiler, but which cuts a groove into it and glances off, is likely to cause an explosion, while the projectile which penetrates the boiler may not cause an explosion, but as it of course lets out the hot steam at great pressure into the boat, it not only stops the speed by degrees, but it makes it impossible to remain under deck, so that the torpedo-boat becomes unmanageable. In both cases the object is thus gained of stopping the boat, as does also a bent or damaged piston or connecting rod, or a hole in the cylinder, fire-box, or slide-box.

$A$ solid bullet which retains its cnergy, after penetrating the skin, is thus much more effective for this purpose than a shell, the small fragments of which have very little energy left unless the shell is so large and breaks into so few pieces that each fragment has weight cnough to do any considerable damage.

I do not think it probable that a torpedo-boat will attack except at night or in rain or mist, and before the gun can be got ready to fire at it, the torpedo-boat will probably be within 300 yards, a distance which it takes only half a minute to ran. It is therefore of the very greatest importance than an anti-torpedo-boat gun should be able to fire extremely quickly at short range; and I do not think that the torpedo-boat can be stopped either by killing the stoker, who is in front of the boiler, or by letting in water through the skin of the boat: thus I think that solid projectiles will always be used in preference against torpedo-boats with a view to smash the machinery or pierce the boiler.

The British Gorernment has signed an international convention, the practical result of which is to limit shells to a minimum calibre of $1 \frac{1}{2}$-inch, and MIr. Hotchkiss, whose gun was tried in Portsmouth, has adopted this calibre. His shells, howerer, are only about one-half of the proper weight for this calibre, and the initial velocity only about 1,300 feet. The penetrating power with over $1 \mathrm{lb}$. steel bullets is, therefore, only about the same as mine with less than $\frac{1}{2} \mathrm{lb}$. steel bullets, while the Hotchkiss common shell has even less penetration. At the final runs of the trials at sea at Spithead last month from 500 yards $\mathrm{up}$ to $\mathbf{1 0 0}$ yards distance from the torpedo-boat model, my gun scored 66 lits per minute against Hotchkiss 15 hits per minute. In the half minute which we would in reality probably have to fire, as above named, Hotchkiss's gun would have scored 7 hits, which, if solid steel shots, may perbaps have been enough to stop the boat; but my corresponding 33 hits in the same half minute would have done so more safely.

In several foreign reports the percentage of hits out of shots fired has been brought prominently forward; but I beg to warn against this as misleading, because the only important point is, how many hits 
I can score with a weapon in a given number of seconds? The question of how many shots I have to fire in order to secure these lits has nothing at all to do with it, because we have so seldom a naval war, and torpedo attacks take place so seldom during a naval war that the cost of this lind of ammunition fired in action is infinitesimal com. pared to the cost of practice ammunition in time of pence.

My rolley-firing guns are also useful in preventing an enemy from serving or letting off a Whitehead torpedo within its range, because no such torpedo could be sent off under my repeated rolleys unless the torpedo were fired from under water.

\section{Larger IFachine Guns for Naval Service.}

While I thus hold to my 1-inch volley-firing gun as the best weapon for defence against torpedo-boats, I am quite alive to the fact that, for general service on board, a shell-firing machine gun would be most effective against unarmoured vessels.

For this purpose the projectile should have the power of penetratingr two $\frac{1}{2}$-inch steel plates at an acute angle, so as to be able to burst the shell inside the bulwarks of any unarmoured ship afluat.

Our $1 \frac{1}{3}$-inch and $1 \frac{7}{8}$-inch guns will therefore fire $1 \frac{3}{4} \mathrm{lbs}$. and $3 \frac{1}{2} \mathrm{lbs}$. shells respectively, which, with an initial relocity of 1,700 to 1,800 feet (proportion of charge to projectile $1: 3$ ), will give per calibre nearly double the penetration of the same calibre of any revolving system with which $I$ am acquainted.

In order to fire these with a rapidity of from 15 to 20 shots per minute (when aiming), I only require one barrel, which makes my gun only half the weight of revolving guns of the same calibre; but besides this gun, which is now ready, I also make volley-firing gans of $1 \frac{1}{2}$-inch calibre, which, with the same weight as the corresponding revolving gun, fires twice as rapidly. The greater woight of $\mathrm{my}$ shells for each given calibre gives me, besides the greater penetration, also the adrantage that the shells, after penetration, break up into much heavier fragments, which better retain the energy for doing damage afterwards.

\section{Conclusion.}

And now, what is the outcome of all this so far as the British Army and Nary are concerned? It is hard to suppose that England will ever be engaged in offensive operations except as a diversion in favour of defence at some other point of her vast territory; and it is more especially for defence that these machine guns are most suitableeconomising the lives of British soldiers and sailors, who are dear not only in a patriotic, bat also in a pecuniary sense, and whose brains and energies are sufficient, if well armed, to hold their own even against the large odds of all comers.

It is true that the world is to a large extent for and not against England, but still there are clouds on the horizon which may call for active measures of defence over lines so vast that not a ship could be spared. 
The defence of the Navy against torpedo-boats and the armament of the cruizers, which have to protect the commerce and communications with the Colonies, are most important subjects, considering the enormons commercial interests at stake-interests which cause much of the civilization of mankind to be bound up in the preservation and progress of the British Empire.

The cost of the maintenance of this defence and of constantly improved armaments, is the "insurance premiam" paid by Great Britain for the security of her Empire-a very low premium, considering the value of the property-and I should feel very proud if I might flatter myself that I hare contributed something which, even in the smallest degree, can have a decisive influence upon the strength of this defence, or, in other words, on the preservation of peace.

Miajor E. Rogers, Stafr Onicer of Pensioners, F.R.G.S. : I must say that I am nstonished that the question of the mitrailleuse has not yet been definitely settled. It takes my mind back to the year 1875, when I gare a lecture here upon the same subject. I thought then that some progress rould hare been made, but none seems to hare been up to tho present day. Then I go back to 1872 , when we heard in this theatre a paper from our late lamented friend Colonel Fletcher, upon which occasion some most eninent men gave us the benefit of their experiences. A Coumittee had previously met and had gone thoroughly into the question, and it was then decided by them that the Gatling gun was the best system that had then been brought forward by the sereral inrentors who competed. Now JIr. Nordenfelt has taken the field. I disclaim any intention to draw invidious comparisons between the Gatling gun and the Nordenfelt. This Institution is not for the purpose of entering into any detailed criticism of that nature. I look upon it rather as a sort of intermediate tribunal where the inventor comes and airs his theories, and tells us what he has to say, and where perhaps he is to some extent criticized; but erentually he has to bo handed orer to a Select Committee at Shoeburyness, and there the question between the Gatling gun and the Nordenfelt gun will be determincd. The Gatling gun has nerer had a proper opportunity of being tried either in peace or in war. It was sent out during the Ashantee War, but it was mounted upon a narrow.guage carriage, which was no doubt suitable to go through a woodland country, but it was top-beavy, upsets mere frequent, and cousequently the gun could not be taken to the front. It was left by Sir Garnet Wolseley to command the bridge-hend at the Prah, and as you may remeinber it was fired into that river on one occasion for the cdification and amusement of an Ashantee warrior, who, when he ear the effect of it, shook his head gravels, raised his hands to hearen, and went home and hanged himself! A few guns were also sent out to Nutal. I volunteered to go out myself with a Gatling, but not with such guns as were cmployed there, which were of an obsolete pattern-the old pattern introduced in 1872. The guns that I wanted to go out with were of a far superior make and perfection of mechanism. I had some trials with them at Chester (indeed I drilled the Volusteer Artillery there to their use), and I was prepared to employ these guns practically against the enemy. The military authorities, howrerer, did not consent to my proposal. At Ulundi the guns no doubt did exceution. I regret that there do not appear to be any Artillery Officers present who could tell us what happened at Ulundi. I understand that a paper was read a few days ago on this subject at the Artillery Institution, Woolwich, but no one has come forward here to say what happence in the Zulu War with regard to the action of the Gatling gun. I believe the report of our friend Major Oren, R.A., has nerer been published. Were he in England, no doubt we mould hase learned ere this the actual facts. The gun has had, I contend, no chance of showing its powers in war. With regard to peace, the trials hitherto made, particularly at Shoeburyness, hare been carried out with a bad cartridge. The trials made there the other day prored nothing but that the Borer 
ear ridge is utterly worthless as ammunition for automatic firearms. The trials later on will, I hope, be conducted with a better class of ammunition. Mr. Nordenfelt his stated that he cloes not consider his systen as competing with the artillery, because he thinls field guns are now so perfect. (Mr. Nondexfect : I did not say that.) It was prored by the Committee in 1872 that the effects of tho Gatling gun were equal to those of three field guns firing shrapnel; that is, the superiority of the Gatling in regard to the number of hits obtained was as three to one. There can be no doubt, therefore, that Gatling guns are able to compete with field guns as man-slaying reapons. No doubt the mitrailleur is incapable of doing any damage to matériel on shore: it can, in a word, do nothing that the best rifle with the best ammunition cannot do; but within that scope it is quite equal to any shell-firing gun, and it produces effects infinitely superior to case-fire, as was admitted by Artil. lery Officers in the discussion on the lecture given by me. With regard to the difliculty in the supply of ammunition, there is one suggestion I should like to take this opportunity of making. There ras a paper read not long ago by Major Geddes of the 53rd Regiment upon "Manual Transport;" and it appears that the wheel proposed (which I would suggest should be used as part of the equipment of machine guns) is capable of carrying 2,000 rounds of ammunition as well as other supplies, in a country where there is no mule or horse transport. Sir, I hare heard this remark from Colonel C. Brackenbury in this Institution, "We have the best mitrailleur extant, and the " only range finder; how is it that they hare not been used in the autumn mancu" vres?" And I would ask, why hare not Gatling or other machine guns been used in the autumn manceurres? I understand that the objection is that they do not fire blank ammunition; but there is no practical dificulty about that. If a Gatling gun were giren to the troops at Aldershot, I am sure the General commanding could show what would be its use and status in war, by the tactical use of it in peace. The lecturer said something (which $T$ should like to correct) about Gatling guns not being rolley-firing guns. Neither is the Nordenfelt gun. Mr. Nordenfelt calls it a colley-firing gun, butit is simply a repeating gun; and when he wants to get accuracy he does not tire so quichly. The mpidity of the Gatling and the rapidity of the Nordenfelt are about equal. It is eaid that the Gatling system is only capable of a small-bore fire, and is therefore not a fit gun for torpedo serrice. There is no question, theoretically speaking (I spak under correction), but that a gun to repel torpedo boats must be a large calibre gun. It would seem from the lecturer's remarks that the Gatling is incapable of being constructed as a Iargebore gun; but I hare myself seen in the naral Service sereral 0.65 guns that could bo used as torpedo-boat repellers if the ammunition were changed. As to this point, I may mention that many years ago I suggested to Dr. Gatling that he should employ with his guns stcel-pointed bullets. I liad myself a sporting Jacob rifle with zine-capped bullets, and I remenber smashing witl one or two rounds of these pointed bullets a regulation target at 400 sards. When the question of repelling torpedo-hoats aroso during the Russian WVar, I repcated that suggestion, and asked Dr. Gatling to manufacture nmmunition to pierce torpedo-boats. Mr. Nordenfelt then took it up. But I reiterate that therc is no reason why the Gatling gun should not be adapted to torpedo serrice.

The Cnamdrax : If there is any one here who has scen these guns used in actunl service, we shall be gl id to hear any remarks from him.

Commander Corris, R.N.: I do not see any guard to the Fordenfelt gun. It scems to me'tlat one gun might be fighting a duel with another. I should like to know if there is any slield provided?

Admiral SeLwis : I should like to refer to a matter which gires me the grentest pleasure. Nearly ten years ago Mr. Daw obtained a prize for a thoronghly gool cartridge, not quite so good for some purposes as the solid-dram cartridge that came a litfle after it, but possessing very great adrantages. Had wo attended to our cartridges first, we should have been able to use machine guns with a perfect rifle, and we should have begun at the right end instead of at the wrong.end of the whole question. Unfortunately, we committed a rery great error. I said so at the time, and $I$ an sorry $I$ was not listened to. But that is not so necessary to refer to as the fact, that delas in such a matter is at this moment extrenely dangerous. If we sro to be left in the position of having a cartridge that we know is not a good one, 
with which no machine gun can work successfully, until war breaks out, I think there is erery probability that we shall find other nations ahead of us, and we shall regret too late not haring done what we ought to hare done. If $I$ had any weight at all with the spending department, I should press on their consideration the fact that it is cleaper to do the right thing at once; that delay will only land them in a greater expense at last, and that there is really no reluctance on the part of the taxpayers to provide efficient weapons when they are asker to do so. Of course it is not-necessary in this Institution to make comparisons between rival inrentors of machine guns. We hope that each inrentor will do his best. We are certain that he will get perfectly fair trials bere, and we hope be may be able to bring forward his points so strongly as to convince not only the Cornmittee, but his antagonists, which will be a more difficult matter. I may be permitted to define what is the true use of the different sorts of machine guns. It is quite clear that the emall-bore mitrailleuse must come into play for all military purposes. If re are to hare a machine of the greatest ralue against uncorered troops-not to compete with our artillery, which it nerer can do, because it cannot pierce stone walls or carthworks-against troops wherever they are scen en masse, or, in some cases, where they are not seen at all, as the Turks found out, for at a long range by corering the ground they killed more Russians than were killed in the assaults-if we are to hare that hind of gun, we must be limited by the cartridge that we have for our rifle, whaterer that may be. Now, I see here with the greatest pleasure a MartiniHenry solid-drawn cartridge, and I am told that some such cartridge is to be idopted. I only hope that some day soon we may arrive at some final decision as near perfection as that; then we shall hare a cartridge for our machine gun and for our rifle, and there mill be no mistake as to what anmunition is brought up. You remember what the Turks were able to do, fring in the air, with a rery slight knowledge of where the supports of the Russians were, when they were adrancing near Plerna, lying down, be it recollected, among the rine trees. The companies were reduced to mere skeletons. In too many instarces the men did not get up when the Officer called to them, and he found that they had been shot through the back. If we recollect what the 'Turks did on that occasion, we may easily imagine what rolley-firing from a mitrailleuse would do, aided by a balloon to indicate the direction and the distance. The gun may be of very great use in that way and in ways that are not at present thought of at all, but it certainly cannot come into use where shell guns ought to be brought to the front. In regard to the naral use of machine guns, we hare to deal with a totally different condition of things. In the ship there is no difficulty in carrying any number of different sorts of ammunition, and they will all be brought up to their separate guns with the utmost certainty and rapidity. It is not like a transport train, which mag hare to go up through smoke, and may not get at the right place. We hare nerer any difficulty, when we hare fire or six guns of different calibre, in getting ammunition for each of them. It is clear that for a torpedo attack nothing short of a gun that will pierce the shell of the boat, and if possible the boiler, will be of any ralue whatever. The boiler question is a rery serious one; and if we are to consider the torpedo-boat as she at present exists, with the boiler taking up the larger position of her midship both laterally and longitudinally, the extreme liability of its being pierced, and the fatal results of any escape of steam, as MIr. Nordenfelt has said, below deck, and the impossibility of any other than a fatal result to the attack,. think we shall see that machine guns of large calibre are very well worth carrging for that purpose alone. I should separate those entirely from those which are raluable for disembarkation, or for protecting the landing of boats, or resisting a mere ordinary boat attack.. There is certainly a tendency in modern days, both in the Army and the Nary, to cconomize our men. I do not beliere that to any large extent guns like these can he left on the deck of an ironclad exposed to a distant fire. There would be rery little left on an ironclad, certainly not the boats, or any of those beautiful arrangements which we ece hung outside the turrets protected by a thin iron plate, if protected at all. I do not think anything could be left there; I do not see why you s)ould leare them there during an attack. I think they ouglit to be so protected and kept as that they can be put into place at the moment when they are requircd during a naral attack, always excepting the case of a torpedo attack at night or 
during mist in the day. The one question that we want to hare solved immediately, and which I hope this mecting will adrocate being done with all the energy that can be put into it, is the question of the cartridge, in order that both rifles and macline guns may be properly constructed for a proper cartridge, whaterer may be the calibre decided on for each purpose.

Major Lidary: A question has been ashed as to what the Gatling guns did at Ulundi. I was not there myself, but I had information from one Staff Oflicer who was present, and from another who had to report on what was done, and their statement mas that two Gatling guns were placed upon the flanks of the square at Ulundi, and no sooner were they brought into action than they jambed, and were utterly useless during the rest of the day.

AIajor Rogers : I hope this meeting will not carry away a wrong impression. It was stated in the paper read the other night at Woolwich that 3,000 rounds were fired, and that the guns killed a great many Zulus. But the fact was, the Gatling was of an obsolete pattern. Two guns were sent out from England in the transport that was wrecked, and these were replaced by two sent from the Mauritius, guns that had been there since 1872 I suppose. But the question is whether the men who used the glins understood them.

MIr. Nondesfelt: Is there more than one pattern in the Serrice?

Major Rogels: Yes, there are two calibres.

Mr. TondeNfelt : There is only one pattern.

Major Rocters: They were never preriously issued to the troops; they were built for the Artillery in 1871 ; the pattern is now an obsolete one, and they were not such guns as you will hare to compete with.

Mr. Nondexpelt : I need not make many remarks by way of reply. Major Rogers has made some etatements about the Gatling gun which I am pleased to hear, because what the Gatling gun does well my gun does better still. WVe hare fired blank ammunition, and I hare offered to the authorities to send out one of my guns with blank ammunition. The difference between my gun and the Gatling gun as to rolley firing is rery casily defined : wo do fire rolleys, and the Gatling gun does not. The Gatling of lirge calibre in the Navy is 0.65 ; but I hear that Dr. Gatling is now busy constructing a $1 \frac{1}{2}$-inch gun. I shall be glad to know its weight per calibre. I hare becn asked whether there is a sbield to my guns. There is not, but the $A d$ miralty authoritics are going to put a shield round them, not abore, but below and round the centre, so as to protect the men, their faces only being seen. As the gallant Admiral has already said, I do not suppose the guns will be on deck in a general fight, cxecpt for special purposes and anti-torpedo purposes. With regard to the Boxer cartridge, I admit that it has great faults; but both the gallant Admiral and Major Rogers forgot to notice that my guns did fire orer 10,000 Boxer cartridges at Shoeburyness with tremendous rapidity, and there were only two that did not act properly. Dr. Gatling did not sueceed in firing his thousand shots coneccutirely at all. I admit that he will probahly do better with a solid cartridge. 1 cannot speal too higlly of the fairness of trials in England. Everything was done, both at. Portsmouth and at Shoeburyncss, in the most marrellously straightforward manner. Crews hare been trained for both guns, and ererything has been done in the fairest way. I think all the competing inrentors will agree that they have been treated most kindly and fairly. The gallant Admiral spoke about hitting the Turks. Well, that means hitting with fair accuracy; but hitting with accuracy at Shocbury. ness is a question of inches and fractions of inches. When you hare decimals of inches at 900 yards that is a rery different thing from ordinary firing. I should be rery pleased if the ddmiralty would some time or other fire against a boiler with 120 lbs. pressure inside, to see the effect of a shot against a torpedo-boat boiler in action. I will now slrow the action of these guns.

The Cramarax : In all these discussions it is, of course, impossible to prerent a ccrtain amount of rivalry between two different systems. I am sorry there is no Officer present who was with the Naral Brigade under Colonel l'earson before they marched to Ekowe. I was told that two Gatling guns did great execution on that. occasion.

Major Rogens: I think they were naral guns.

The Cuamara: I was told that the guns were rery serviceable. 
Major Rogens: There was a complaint in the dispatch that the men did not understand the gun, that they upset it and damaged the action.

The Cusmmax : With regard to the Nordenfelt s5stem, I understand it is going to have a thorough trial, and as MIr. Nordenfelt acknowledges that the trial will be a fair one, we must await with great interest and anxicty the result of the competition. 1 of course these discussions are so far beneficial that they rentilate the subject, but the real test is, first the trial in time of peace, and, abore all, the trial on active serrice. The defects of the guns then become apparent, and are afterwards corrected. I have only now to ask you to gire your cordial thanks to Mr. Nordenfelt for bringing theso matters before us.

1 Appendices B, C, and D have been supplied by Mr. Nordenfelt since the reading of his paper.-ED. 


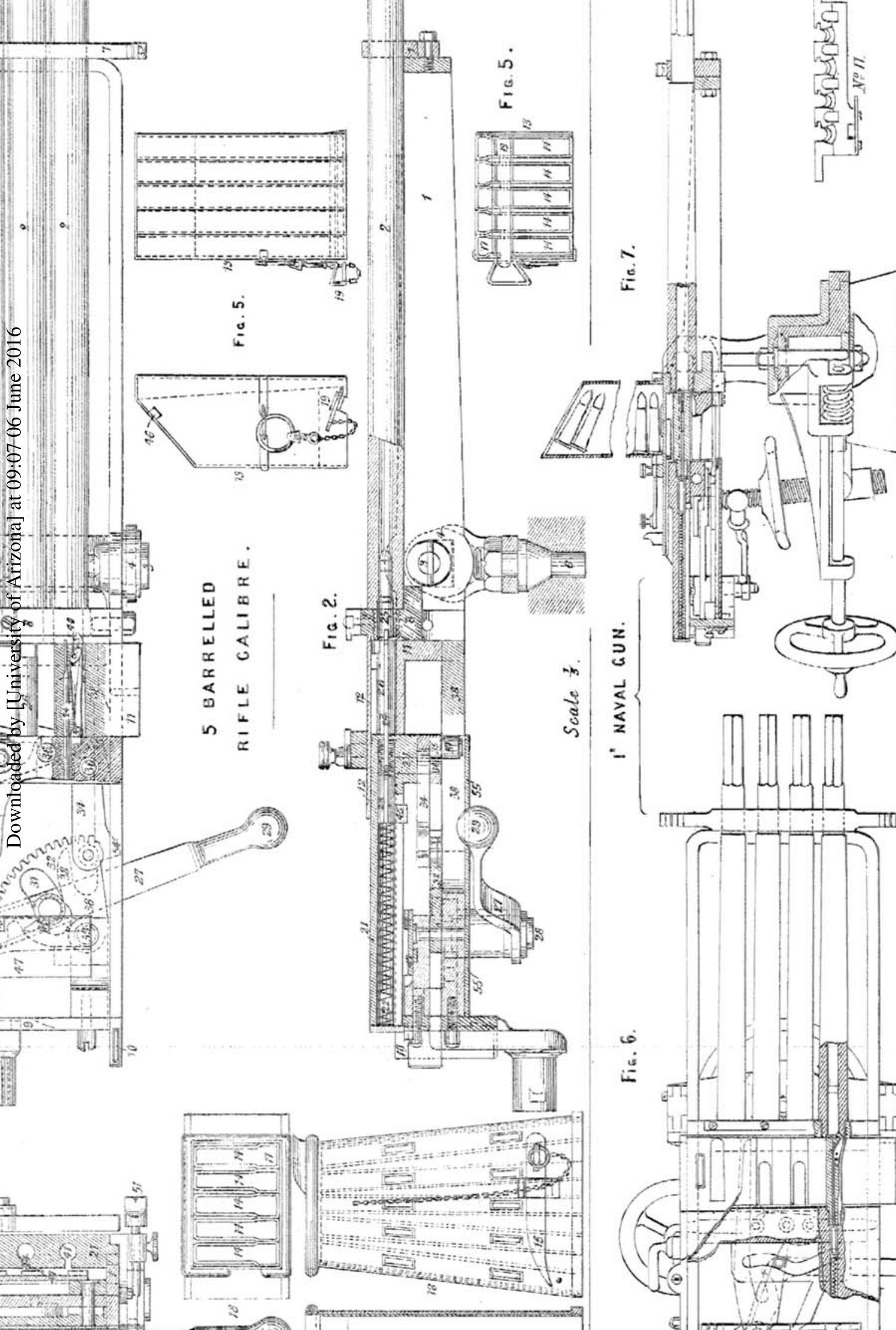

